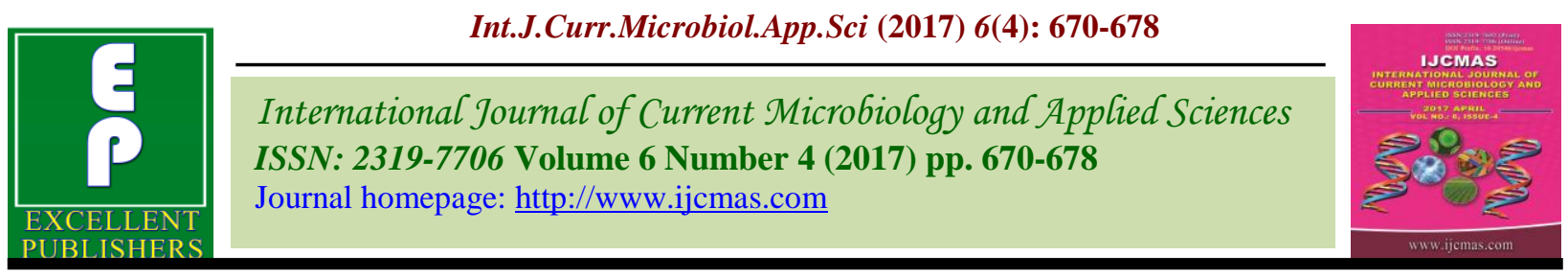

Original Research Article

https://doi.org/10.20546/ijcmas.2017.604.082

\title{
Soil Fertility Status as Influenced by Different Cropping Systems in Hill Zone Acid Soils of Karnataka, India
}

\author{
Prabhudev Dhumgond ${ }^{1 *}$, S.S. Prakash ${ }^{2}$, C.A. Srinivasamurthy ${ }^{3}$ and S. Bhaskar ${ }^{4}$ \\ ${ }^{1}$ Department of Soil Science and Agricultural Chemistry, UAS, Bengaluru, India \\ ${ }^{2}$ Department of Soil Science and Agricultural Chemistry, CoA, Mandya, India \\ ${ }^{3}$ Central AgriculturalUniversity, Imphal, India \\ ${ }^{4}$ Agronomy, Agro-Forestry and Climate change, ICAR, New Delhi, India \\ *Corresponding author
}

\begin{tabular}{|c|c|}
\hline & A B S T R A C T \\
\hline Keywords & \multirow{4}{*}{$\begin{array}{l}\text { The study was conducted to know the soil fertility status of different cropping systems in } \\
\text { hill zone acid soils of Karnataka. In each cropping systems, samples were collected from } \\
\text { two depths }(0-15 \mathrm{~cm} \text { and } 15-30 \mathrm{~cm}) \text { at } 20 \text { locations randomly. Soil characterization } \\
\text { revealed that soils were slightly acidic to moderately acidic in range with low soluble salts. } \\
\text { Surface soils under paddy cropping system recorded higher exchangeable } \mathrm{Al}^{3+} \text { and } \\
\text { exchangeable acidity compared to coffee and areca cropping system. Soils are medium in } \\
\text { available } \mathrm{N} \text { and P status but high in available } \mathrm{K}, \mathrm{Ca}, \mathrm{Mg} \text { and } \mathrm{S} \text { status in all cropping } \\
\text { systems. Amount of DTPA- extractable } \mathrm{Fe}, \mathrm{Mn}, \mathrm{Zn} \text { and } \mathrm{Cu} \text { were higher in coffee and } \\
\text { areca systems compared to paddy system. The content of available nutrients decreased } \\
\text { with depth in all cropping systems. Available nutrients status was lower in paddy system } \\
\text { compared to other two systems. }\end{array}$} \\
\hline $\begin{array}{l}\text { Soil Fertility, } \\
\text { Different } \\
\text { Cropping } \\
\text { Systems }\end{array}$ & \\
\hline Article Info & \\
\hline $\begin{array}{l}\text { Accepted: } \\
\text { 06 March } 2017 \\
\text { Available Online: } \\
10 \text { April } 2017\end{array}$ & \\
\hline
\end{tabular}

\section{Introduction}

Soil fertility is one of the important factors controlling the crop yield. Soil related limitations affecting the crop productivity including nutritional disorders can be determined by evaluating the fertility status of the soils. Soil testing provides the information about the nutrient availability of the soil upon which the fertilizer recommendation for maximizing crop yield is made. According to Wang et al., (2001) climate and geological history are importance factors to affecting soil properties on regional and continental scales. However, land use may be the dominant factors of soil properties under small catchment scale. Land use and soil management practices influence the soil nutrients and related soil processes, such as erosion, oxidation, mineralization, and leaching, etc (Celik, 2005; Liu et al., 2010). As a result, it can modify the processes of transport and re-distribution of nutrients. In non-cultivated land, the type of vegetative cover is a factor influencing the soil organic carbon content (Liu et al., 2010). Moreover, soils through land use change also produce considerable alterations (Fu et al., 2000), and usually soil quality diminishes after the cultivation of previously untilled soils (Neris et al., 2012). Thus, land use and type of vegetation must be taken into account when 
relating soil nutrients with environmental conditions (Liu et al., 2010). The particular nature of the typical rugged relief with slopes subjected to cultivation for many years in the study area had lead to decline in soil fertility. Therefore, there is special need for the analysis of soil nutrients in relation to land use. Such a local analysis is necessary to estimate nutrient storage in plantation and cultivated ecosystems (Wang et al., 2001); therefore this research was initiated to investigate the influence of different land use types on selected properties of the soil in acid soils of Karnataka.

\section{Materials and Methods}

\section{Study area}

Chikmagaluru and Hassan districts are located on the eastern sides of the Western Ghats, in the southern part of Karnataka state (zone-9). Chikmagaluru and Hassan districts have total geographical area of $7201 \mathrm{~km}^{2}$ and 6826.15 $\mathrm{km}^{2}$, respectively. In this present investigation, soil samples from two depths (0-15 and 15-30 cm) were collected from paddy, areca nut and coffee cropping systems in Hassan and Chikmagaluru districts, Karnataka state. The crops in each of the systems are paddy, areca nut and coffee, in these later two are perennial crops and in paddy system only one crop is taken per year. Soil samples were collected in 20 locations from each cropping system. At each location sample was collected from 8 to 10 spots and pooled to get one composite sample for each depth. In all, 120 soil samples (60 from 0 to $15 \mathrm{~cm}$ and 60 from 15 to $30 \mathrm{~cm}$ depth) were analyzed for characterizing the acid soils.

Collected soil samples were analyzed for $\mathrm{pH}$ and electrical conductivity (Sarma et al., 1987). The composite soil samples were analyzed for available nitrogen (Subbiah and Asija, 1956), available $\mathrm{P}_{2} \mathrm{O}_{5}$ (Bray and Kurtz, 1945), neutral ammonium acetate extractable
$\mathrm{K}_{2} \mathrm{O}$ (Jackson, 1973), organic carbon (Walkley and Black, 1934) and available sulphur (Chesnin and Yien, 1951). The available $\mathrm{Zn}, \mathrm{Cu}, \mathrm{Mn}$ and $\mathrm{Fe}$ extracted with DTPA (Lindsay and Norvell, 1978) were determined on an Atomic Absorption Spectrophotometer. The boron content in the soil was determined by boiling soil with water at 1:2 soil to water ratio for 5 minutes and filtered and it is estimated using AzomethineH reagent (John et al., 1975). Data obtained were subjected to statistical test using split plot design.

\section{Results and Discussion}

\section{Soil reaction (pH) and electrical conductivity (EC)}

Soil $\mathrm{pH}$ is an important property which helps in understanding processes and speciation of chemical element in soil. The soil $\mathrm{pH}$ did not differ significantly with depth. But the $\mathrm{pH}$ value of surface soil was (5.46 \pm 0.55$)$ slightly higher than subsurface layer $(5.32 \pm$ 0.54). However, the $\mathrm{pH}$ in soils under arecanut cropping system was significantly higher than $(5.57 \pm 0.41)$ that recorded for coffee $(5.30 \pm 0.5)$ and paddy $(5.22 \pm 0.65)$. Further, the interaction was no significant (Table 1). The EC, which is a measure of total soluble salt content in soil, was in general low in these soils. The EC value in the surface soil

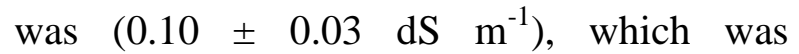
significantly higher than that recorded in lower soil depth $(15-30 \mathrm{~cm})$. The EC value under different cropping system and interaction between soil depth and cropping system was no significant (Table 1).

\section{The exchangeable acidity and aluminium}

Exchangeable acidity in the soil was in the range of $16.12 \pm 9.97$ to $21.0 \pm 8.90 \mathrm{~m}$.eq 100 $\mathrm{g}^{-1}$ in different cropping systems (Table 2). Among different cropping systems paddy system had higher exchangeable acidity (21.0 
\pm 8.90 m.eq $100 \mathrm{~g}^{-1}$ ) compared to coffee $\left(16.12 \pm 9.97 \mathrm{~m} . e q 100 \mathrm{~g}^{-1}\right)$ and areca $(18.12 \pm$ 5.52 m.eq $100 \mathrm{~g}^{-1}$ ) systems. Further, the interaction between depth and cropping systems was no significant.

The exchangeable Al values were found no significant either due to depth or cropping systems. However, surface soils recorded higher $\left(17.17 \pm 12.16\right.$ m.eq $\left.100 \mathrm{~g}^{-1}\right)$ exchangeable $\mathrm{Al}$ content compared to subsurface layer $\left(16.42+7.43 \mathrm{~m} . \mathrm{eq} 100 \mathrm{~g}^{-1}\right)$. Among cropping systems, areca recorded lower exchangeable $\mathrm{Al}$ content $(14.87 \pm 8.01$ m.eq $\left.100 \mathrm{~g}^{-1}\right)$ than paddy $(18.75 \pm 10.81 \mathrm{~m} . \mathrm{eq}$ $\left.100 \mathrm{~g}^{-1}\right)$ and coffee $\left(16.75 \pm 10.0 \mathrm{~m} . e q 100 \mathrm{~g}^{-}\right.$ $\left.{ }^{1}\right)$.

\section{Soil organic carbon}

The soil organic carbon content differed significantly with depth. The soil organic carbon content of surface soil was significantly higher $\left(24.2 \pm 6.6 \mathrm{~g} \mathrm{~kg}^{-1}\right)$ than lower soil layer $\left(19.3 \pm 6.8 \mathrm{~g} \mathrm{~kg}^{-1}\right)$. Similarly, SOC content under coffee cropping system was significantly higher $\left(29.0 \pm 5.4 \mathrm{~g} \mathrm{~kg}^{-1}\right)$ than that recorded for areca $\left(20.47 \pm 6.5 \mathrm{~g} \mathrm{~kg}^{-1}\right)$ and paddy $\left(18.5 \pm 5.8 \mathrm{~g} \mathrm{~kg}^{-1}\right)$. Further, the interaction was no significant.

\section{Major nutrients}

Available $\mathrm{N}$ and $\mathrm{P}$ content were medium and $\mathrm{K}$ status was higher in both depths and in different cropping systems. However, significantly higher available $\mathrm{N}, \mathrm{P}$ and $\mathrm{K}$ content were noticed in surface soil $(453.7 \pm$ $65.2 \mathrm{~N} \mathrm{~kg} \mathrm{ha}^{-1}, 32.7 \pm 8.4 \mathrm{P}_{2} \mathrm{O}_{5} \mathrm{~kg} \mathrm{ha}^{-1}$ and $467.7 \pm 149.1 \mathrm{~K}_{2} \mathrm{O} \mathrm{kg} \mathrm{ha}{ }^{-1}$, respectively) under paddy, areca and coffee cropping systems, respectively. The coffee system recorded higher $\mathrm{N}, \mathrm{P}$ and $\mathrm{K}$ values (426.5 \pm $58.2 \mathrm{~N} \mathrm{~kg} \mathrm{ha}^{-1}, 31.1 \pm 7.1 \mathrm{P}_{2} \mathrm{O}_{5} \mathrm{~kg} \mathrm{ha}^{-1}$ and $452.1 \pm 110.5 \mathrm{~K}_{2} \mathrm{O} \mathrm{kg} \mathrm{ha}{ }^{-1}$, respectively) compared to areca and paddy.

\section{Secondary nutrients}

Significantly lower $\mathrm{NH}_{4} \mathrm{OAC}$ extractable $\mathrm{Ca}$ and $\mathrm{Mg}(3.43 \pm 1.02$ and $2.40 \pm 0.80 \mathrm{C} \mathrm{mol}$ $\left.(\mathrm{p}+) \mathrm{kg}^{-1}\right)$ and available sulfur values $(17.3 \pm$ $4.5 \mathrm{mg} \mathrm{kg}^{-1}$ ) were observed in paddy cropping system. The surface soils recorded higher $\mathrm{NH}_{4} \mathrm{OAC}$ extractable $\mathrm{Ca}$ and $\mathrm{Mg}$ and available sulfur content $(5.54 \pm 2.06,3.34 \pm$ $0.96 \mathrm{C} \mathrm{mol}(\mathrm{p}+) \mathrm{kg}^{-1}$ and $22.9 \pm 4.6 \mathrm{mg} \mathrm{kg}^{-1}$, respectively) compared to subsurface soil layer (Table 4).

\section{Available micronutrients}

The status of DTPA- extractable Fe, Mn, Zn, $\mathrm{Cu}$ and hot water soluble $\mathrm{B}$ in different soil depths under different cropping systems are presented in table 5 and 6 . The DTPA extractable $\mathrm{Fe}, \mathrm{Mn}$, and $\mathrm{Cu}$ content in surface soil $(28.21 \pm 6.19,7.37 \pm 4.13$ and $4.34 \pm$ $1.35 \mathrm{mg} \mathrm{kg}^{-1}$ ) were significantly higher than that observed in sub surface soil $(21.63 \pm$ 4.97, $7.71 \pm 4.28$ and $3.07 \pm 1.20 \mathrm{mg} \mathrm{kg}^{-1}$ respectively). Whereas, DTPA-Mn and hot water soluble boron content recorded in the surface soil was statistically at par with the values recorded in the sub surface soil layer. The content of all the micronutrients varied significantly in soils under different cropping systems except boron. Amount of DTPAextractable $\mathrm{Fe}, \mathrm{Mn}, \mathrm{Zn}$ and $\mathrm{Cu}$ was $28.40 \pm$ $3.90,9.86 \pm 4.24$ and $1.57 \pm 0.39,4.31 \pm 1.30$ $\mathrm{mg} \mathrm{kg}^{-1}$, respectively in soils under coffee system were higher compared with paddy system $21.19 \pm 4.90,5.10 \pm 2.00$ and $1.13 \pm$ $0.31,3.08 \pm 1.01 \mathrm{mg} \mathrm{kg}^{-1}$, and areca system $25.08 \pm 4.90,6.04 \pm 2.80,1.53 \pm 0.40,3.70 \pm$ 1.21 respectively. Similarly, higher content of Fe $\left(33.04 \pm 3.63 \mathrm{mg} \mathrm{kg}^{-1}\right), \mathrm{Mn}(10.5 \pm 4.96$ $\left.\mathrm{mg} \mathrm{kg}{ }^{-1}\right), \mathrm{Zn}\left(1.99 \pm 0.47 \mathrm{mg} \mathrm{kg}^{-1}\right)$ and $\mathrm{Cu}$ $\left(5.08 \pm 1.47 \mathrm{mg} \mathrm{kg}^{-1}\right)$ was recorded in the surface soils under coffee system. However, the interaction effect between depth and cropping system was found significant on $\mathrm{Fe}$, $\mathrm{Mn}$ and $\mathrm{Zn}$ and it was nonsignificant on $\mathrm{Cu}$ and boron. 
Table.1 Soil reaction $(\mathrm{pH})$ and electrical conductivity (EC) of acid soils of hill zoneunder different cropping systems

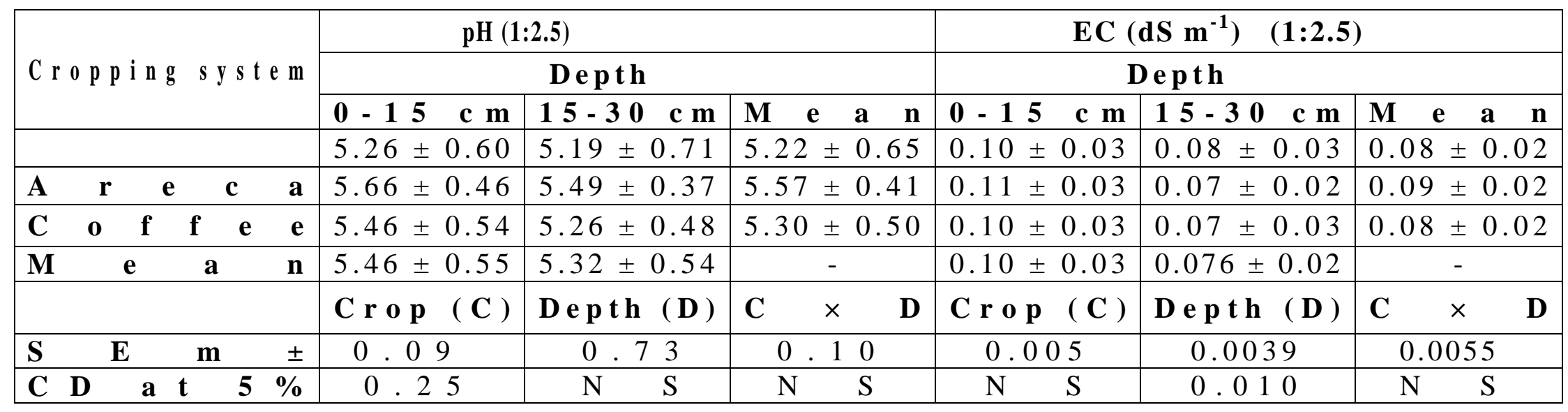

Table.2 Soil exchangeable acidity, aluminum and organic carbon content in acid soils of hill zone under different cropping systems

\begin{tabular}{|c|c|c|c|c|c|c|c|c|c|}
\hline \multirow{3}{*}{ Cropping system } & \multicolumn{3}{|c|}{ Exchangeable acidity $\left(\mathrm{m.eq} 100 \mathrm{~g}^{-1}\right)$} & \multicolumn{3}{|c|}{ Exchangeable aluminum(m.eq $\left.100 \mathrm{~g}^{-1}\right)$} & \multicolumn{3}{|c|}{ Soil organic carbon $\left(\mathrm{g} \mathrm{kg}^{-1}\right)$} \\
\hline & \multicolumn{3}{|c|}{ Depth } & \multicolumn{3}{|c|}{ Depth } & \multicolumn{3}{|c|}{ Depth } \\
\hline & 0 - 15 c m & 0 - 15 c m & $\begin{array}{llll}\mathbf{M} & \mathbf{e} & \mathbf{a} & \mathbf{n} \\
\end{array}$ & 0-15 c m & $15-30 \mathrm{~cm}$ & $\begin{array}{llll}\mathbf{M} & \mathbf{e} & \mathbf{a} & \mathbf{n} \\
\end{array}$ & 0 - 15 c m & $15-30 \mathrm{~cm}$ & 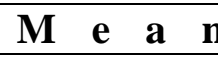 \\
\hline$P$ a d d y & $21.51 \pm 11.1$ & $20.50 \pm 6.67$ & $21.0 \pm 8.90$ & $19.25 \pm 13.30$ & $18.25 \pm 8.31$ & $18.75 \pm 10.81$ & $21.1 \pm 5.7$ & $16.5 \pm 5.9$ & $18.5 \pm 5.8$ \\
\hline A r e c a & $21.01 \pm 6.41$ & $15.25 \pm 4.72$ & $18.12 \pm 5.52$ & \begin{tabular}{|l|}
$16.01 \pm 9.11$ \\
\end{tabular} & \begin{tabular}{|l|}
$13.75 \pm 7.05$ \\
\end{tabular} & $14.87 \pm 8.01$ & $22.4 \pm 6.2$ & $18.55 \pm 6.8$ & $20.47 \pm 6.5$ \\
\hline Cof f e e & $17.25 \pm 12.5$ & $15.02 \pm 7.43$ & $16.12 \pm 9.97$ & $16.25 \pm 13.84$ & $17.25 \pm 6.38$ & $16.75 \pm 10.0$ & $29.0 \pm 5.4$ & $23.6 \pm 6.0$ & $26.0 \pm 5.9$ \\
\hline M e a n & $19.92 \pm 10.3$ & $16.92 \pm 6.77$ & - & $17.17 \pm 12.16$ & $16.42 \pm 7.43$ & - & $24.2 \pm 6.6$ & $19.3 \pm 6.8$ & \\
\hline & Crop (C) & Depth (D) & $\mathbf{C}$ & Crop (C) & Depth (D) & C $\times$ & Crop (C) & Depth (D) & $\mathbf{C}$ \\
\hline $\begin{array}{lll}\mathbf{S} & \mathbf{E} & \mathbf{m}\end{array}$ & 1.32 & 1.28 & $\begin{array}{llll}1 & . & 8 & 1\end{array}$ & $1 \cdot 3 \quad 3$ & 1.58 & 2.24 & 93 & . 8 & 1 \\
\hline CD at $5 \%$ & $\begin{array}{lll}3 & 7 & 8\end{array}$ & 3.61 & $\mathrm{~N}$ & & $\mathrm{~N} S$ & & & 2 & $\mathrm{~N}$ \\
\hline
\end{tabular}


Table.3 Available major nutrients status in acid soils of hill zone under different land use systems

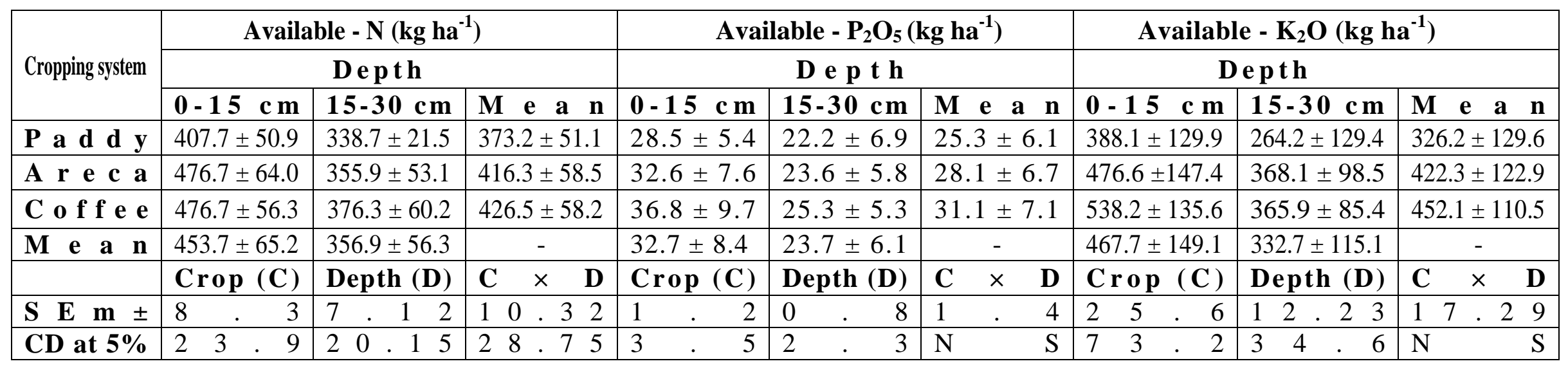

Table.4 Available secondary nutrients in acid soils of hill zone under different cropping systems

\begin{tabular}{|c|c|c|c|c|c|c|c|c|c|}
\hline \multirow{3}{*}{ Cropping system } & \multicolumn{3}{|c|}{$\mathrm{NH}_{4} \mathrm{OAC}-\mathrm{Ca}\left(\mathrm{C}\right.$ mol $\left.(\mathrm{p}+) \mathrm{kg}^{-1}\right)$} & \multicolumn{3}{|c|}{$\mathrm{NH}_{4} \mathrm{OAC}-\mathrm{Mg}\left(\mathrm{C} \operatorname{mol}(\mathrm{p}+) \mathrm{kg}^{-1}\right)$} & \multicolumn{3}{|c|}{ Available-S (mg kg $\left.{ }^{-1}\right)$} \\
\hline & \multicolumn{3}{|c|}{ De pth } & \multicolumn{3}{|c|}{$D$ e p t h } & \multicolumn{3}{|c|}{ Depth } \\
\hline & 0 - 15 c m & $15-30 \mathrm{~cm}$ & M e a n & 0 - 15 c m & $15-30 \mathrm{~cm}$ & M e a n & 0 - 15 c m & $15-30 \mathrm{~cm}$ & M e $\mathbf{a}$ n \\
\hline$P$ a d d y & $3.86 \pm 1.06$ & $3.01 \pm 0.98$ & $3.43 \pm 1.02$ & $2.75 \pm 0.68$ & $2.05 \pm 0.92$ & $2.40 \pm 0.80$ & $19.8 \pm 4.7$ & $15.0 \pm 4.3$ & $17.3 \pm 4.5$ \\
\hline A r e c a & $6.22 \pm 1.83$ & $4.43 \pm 1.13$ & $5.32 \pm 1.47$ & $3.52 \pm 0.81$ & $2.40 \pm 0.75$ & $2.90 \pm 0.78$ & $23.8 \pm 3.6$ & $15.1 \pm 3.4$ & $19.2 \pm 3.5$ \\
\hline Cof f e e & $6.53 \pm 2.04$ & $4.71 \pm 1.32$ & $5.60 \pm 1.60$ & $3.73 \pm 1.08$ & $2.65 \pm 1.58$ & $3.19 \pm 1.33$ & $25.7 \pm 3.6$ & $19.2 \pm 4.1$ & $22.5 \pm 3.8$ \\
\hline M e a n & $5.54 \pm 2.06$ & $4.05 \pm 1.36$ & - & $3.34 \pm 0.96$ & $2.37 \pm 1.15$ & - & $22.9 \pm 4.6$ & $16.4 \pm 4.3$ & - \\
\hline & Crop (C) & Depth (D) & $\mathbf{C}$ & Crop (C) & Depth (D) & $\mathbf{C}$ & Crop (C) & Depth (D) & $\mathbf{C}$ \\
\hline $\begin{array}{llll}\mathbf{S} & \mathbf{E} & \mathbf{m} & \pm\end{array}$ & 0.24 & 0.17 & 25 & 0.20 & $\begin{array}{llll}0 & . & 1 & 1\end{array}$ & 16 & 0.80 & 0.34 & 49 \\
\hline CD at $5 \%$ & 69 & $\begin{array}{llll}0 & . & 5 & 0\end{array}$ & $\mathrm{~N}$ & $\begin{array}{ll}5 & 7\end{array}$ & 33 & $\mathrm{~N}$ & 2.20 & 0 & 40 \\
\hline
\end{tabular}


Table.5 Available micronutrients (Fe and $\mathrm{Mn}$ ) in acid soils of hill zone under different cropping systems

\begin{tabular}{|c|c|c|c|c|c|c|}
\hline \multirow{3}{*}{ Cropping system } & \multicolumn{3}{|c|}{$\operatorname{Iron}\left(\mathrm{mg} \mathrm{kg}^{-1}\right)$} & \multicolumn{3}{|c|}{ Manganese $\left(\mathrm{mg} \mathrm{kg}^{-1}\right)$} \\
\hline & \multicolumn{3}{|c|}{ De pt $h$} & \multicolumn{3}{|c|}{ Depth } \\
\hline & 0 -15 c m & $15-30$ c m & $\mathbf{M}$ & $0-15$ & $15-30$ c m & $\mathbf{M}$ \\
\hline $\mathbf{P} \quad \mathbf{a} \quad \mathbf{d}$ & $22.80 \pm 5.41$ & $19.58 \pm 4.40$ & $21.19 \pm 4.90$ & $5.35 \pm 2.20$ & $4.97 \pm 1.80$ & $5.10 \pm 2.00$ \\
\hline $\begin{array}{lllll}\mathbf{A} & \mathbf{r} & \mathbf{e} & \mathbf{c} & \mathbf{a} \\
\end{array}$ & $28.81 \pm 4.51$ & $21.37 \pm 5.37$ & $25.08 \pm 4.90$ & $6.29 \pm 2.78$ & $5.80 \pm 2.90$ & $6.04 \pm 2.80$ \\
\hline $\begin{array}{llllll}\mathbf{C} & \mathbf{o} & \mathbf{f} & \mathbf{f} & \mathbf{e} & \mathbf{e}\end{array}$ & $33.04 \pm 3.63$ & $23.95 \pm 4.27$ & $28.40 \pm 3.90$ & $10.5 \pm 4.96$ & $9.26 \pm 3.50$ & $9.86 \pm 4.24$ \\
\hline a $\quad \mathbf{n}$ & $28.21 \pm 6.19$ & $21.63 \pm 4.97$ & - & $7.37 \pm 4.13$ & $6.68 \pm 3.35$ & - \\
\hline & Crop $(\mathbf{C})$ & Depth (D) & $\mathbf{C}$ & Crop ( C ) & De pth (D) & $\mathbf{C}$ \\
\hline $\mathbf{m}$ & 7 & 4 & 0 & 6 & 3 & 4 \\
\hline $\begin{array}{llllll}\text { C } & D & \text { a } & \text { t } & 5 & \%\end{array}$ & 9 & 4 & 2 & 7 & $\mathrm{~N}$ & 3 \\
\hline
\end{tabular}

Table.6 Available micronutrients ( $\mathrm{Zn}, \mathrm{Cu}$ and $\mathrm{B}$ ) in acid soils of hill zone under different cropping systems

\begin{tabular}{|c|c|c|c|c|c|c|c|c|c|}
\hline \multirow{3}{*}{ Cropping system } & \multicolumn{2}{|c|}{$\begin{array}{llllll}\mathbf{Z} & \mathbf{i} & \mathbf{n} & \mathbf{c} & (\mathbf{m} & \mathbf{g}\end{array}$} & $\left.\mathbf{k} \mathbf{g}^{-1} \mathbf{1}\right)$ & \multicolumn{2}{|c|}{ Cop p e $\mathbf{r}$ ( $\mathbf{m} \mathbf{g}$} & $\left.k g^{-1}\right)$ & B $\quad \begin{array}{llll} & \mathbf{O} & \mathbf{0} & \mathbf{n}\end{array}$ & ( $\mathrm{m} \mathbf{g}$ & k g \\
\hline & D & $\mathbf{p}$ & h & D & $\mathbf{p}$ & h & D & $\mathbf{p}$ & $\mathbf{t}$ \\
\hline & $0-15$ c m & $15-30 \mathrm{~cm}$ & M e a n & $0-15$ c m & $15-30 \mathrm{~cm}$ & M e a n & $0-15$ c m & $15-30 \mathrm{~cm}$ & M $\quad$ e $\quad$ a $\quad \mathbf{n}$ \\
\hline A r e c a & $1.81 \pm 0.45$ & $1.26 \pm 0.42$ & $1.53 \pm 0.40$ & $4.29 \pm 1.19$ & $3.12 \pm$ & $3.70 \pm 1.21$ & $0.032 \pm 0.012$ & $0.032 \pm 0.011$ & $0.032 \pm 0.011$ \\
\hline Coffee & $1.99 \pm 0.47$ & $1.15 \pm 0.31$ & $1.57 \pm 0.39$ & $5.08 \pm 1.47$ & $3.54 \pm 1.14$ & $4.31 \pm 1.30$ & $0.030 \pm 0.012$ & $0.039 \pm 0.056$ & $0.035 \pm 0.034$ \\
\hline M e a n & $1.72 \pm 0.48$ & $1.09 \pm 0.38$ & - & $4.34 \pm 1.35$ & $3.07 \pm 1.20$ & - & $0.033 \pm 0.013$ & $0.036 \pm 0.034$ & - \\
\hline $\mathrm{m} \pm$ & 07 & 04 & 06 & 23 & 15 & 21 & $\begin{array}{lll}0 & 0 & 4 \\
\end{array}$ & 00336 & $\begin{array}{lll}0 & 0 & 5 \\
\end{array}$ \\
\hline & 21 & 0.12 & 17 & 65 & 43 & S & $N$ & $\mathrm{~S}$ & $\mathrm{~N}$ \\
\hline
\end{tabular}


The acidic soil reaction was attributed to leaching of basic cations as the soils are collected from hill zone which receives an average annual rainfall of 1000-3000 $\mathrm{mm}$. The variation in $\mathrm{pH}$ among soils under different cropping systems may be attributed to variation in rain fall within the zone, topographic position and management practices (Ananth Narayana and Ravi, 1997). Further, as these soils are derived from granite and granite gneiss which are silica saturated igneous and metamorphic rocks, as a result the soils show acidic reaction. The low EC indicate that the soluble salts were leached out of soil under high rainfall area; consequently there was no salt accumulation in these soils (Rao, 1992).

The higher exchangeable acidity in these soils might be attributed to replacement of exchangeable hydrogen plus increased hydrolysis of adsorbed $\mathrm{Al}$ and degree of dissociation of acidic group on clay surface. Similar findings were reported by Ananthnarayana and Ravi (1997). Exchangeable $\mathrm{Al}^{3+}$ was in the range of $14.87 \pm 8.01$ to $18.75 \pm$ $10.81 \mathrm{~m} . e q 100 \mathrm{~g}^{-1}$ under different cropping system (Table 2) the higher exchangeable $\mathrm{Al}^{3+}$ in the soils may be attributed to low $\mathrm{pH}$.

The accumulation of soil organic matter is a function of the amount of plant, animal and microbial inputs received by soil in the past (Brady and Weill, 1996) and the rate at which the biomass input decays. It is also directly related to the amount of organic residues added to the soils, manure and fertilizer application (Banger et al., 2008). Further, the interaction between cropping system and depth was no significant (Table 2). The lower organic carbon content in sub surface layer might be attributed to lower vertical mixing of soils as the soils under coffee and areca are not disturbed by tillage operation

The medium status of available $\mathrm{N}$ and $\mathrm{P}$ and higher status of $\mathrm{K}$ in acid soils may be attributed to recycling of biomass (leaf-litter and residue and addition of manures). It was evident by the fact that these soils had higher soil organic carbon content (Table 3). Variation in available-N in different cropping systems may be attributed to soil organic matter and total-N contents. Continuous application of organic matter is known to enhance both available and total-N content of soil (Mukharjee and Ghosh, 1984; Stangel et al., 1994). Similar result was reported by Korikanthimath et al., (2002). They have reported that SOC content was highly correlated with soil $\mathrm{N}$ and $\mathrm{P}$ content inacid soils. Further, higher accumulation of potassium in horticultural systems was due to excess application is also reported by Chang et al., (2008) and Nagaraja (1997).

The lower exchangeable $\mathrm{Ca}, \mathrm{Mg}$ and available sulphur under paddy cropping system as compared to areca and coffee cropping system might be attributed to leaching loss of these elements as the paddy is usually grown in lower topographic position. Secondly, the soils in hill zone are predominantly kaolinitic, consequently had low negative charge density to hold cation in exchange surface. Further, these cations are not adsorbed; they are susceptible for leaching in high rainfall areas. Besides, the variation may also be attributed to management practices adopted to grow these crops. Application of agricultural lime $\left(\mathrm{CaCO}_{3}\right)$ and dolomite $\left(\mathrm{CaCO}_{3} \mathrm{MgCO}_{3}\right)$ in areca and coffee plantations might have enhanced $\mathrm{NH}_{4} \mathrm{OAC}$ extractable $\mathrm{Ca}$ and $\mathrm{Mg}$. Similarly higher amount of sulfur in coffee and areca cropping systems may be attributed to application of gypsum, $\mathrm{CuSO}_{4}$, and S-containing fertilizers. However, the content of exchangeable $\mathrm{Ca}, \mathrm{Mg}$ and available sulphur was above critical level. Similar observation was also reported by Dharakanath, (1995) and (Nambiar, 1994; Powlson and Johnston, 1994).

The $\mathrm{NH}_{4} \mathrm{OAC}$ extractable $\mathrm{Ca}$ and $\mathrm{Mg}$ and available $\mathrm{S}$ content found in these acid soils of hill zone are within the range reported for acid soils in India. Herojith Singh et al., (2007) reported that acid soils of Manipur have inorganic sulfur content ranged between 10-70 ppm and the higher available sulphur content was attributed to higher organic matter content. 
The content of DTPA Fe, Mn, $\mathrm{Zn}$ and $\mathrm{Cu}$ which is far higher than critical level might be attributed primarily to lower soil $\mathrm{pH}$, as $\mathrm{pH}$ decreases the solubility of these micronutrients increases (Brady and Weill, 2002). Secondly, the higher soil organic carbon content might have enhanced the microbial activity in the soil, and consequent release of complex organic substances (chelating agents) which from stable chelates with these elements thus decreases the susceptibility to precipitation, fixation, oxidation and leaching of micronutrients (Tisdale et al., 1995).In general boron content was lower in soils under different cropping systems. The lower available boron content in acid soils might be attributed to boron sorption to iron and aluminum oxide surfaces of soil minerals (Goldberg and Glaubio, 1985).

In conclusion soil samples collected were slightly acidic to moderately acidic in reaction with low soluble salts. Soil organic carbon concentration of surface soils was generally decreased with increasing depth. The available major, secondary and micro nutrient status was medium to high and higher in coffee cropping system compared to areca and paddy cropping system.

\section{References}

Ananthanarayanaya, R. and Ravi, M. V., 1997, Nature of soil acidity of coffee growing soils of Karnataka. J. Indian Soc. Soil Sci., 45(2): 384-385

Banger, K., Kukal, S. S., Toor, G., Sudhir, K. and Hanumanthraju, T. H., 2008, Impact of long-term additions of chemical fertilizers and farm yard manure on carbon and nitrogen sequestration under rice-cowpea cropping system in semiarid tropics. Plant soil., DOI 10.1007/ss1104-008-9813-z.

Brady, N.C. and R.R. Weil, 2002. The nature and properties of soils, 13th $\mathrm{Ed}$. Prentice- Hall Inc., New Jersey, USA. 960p.

Bray, R. H. and Kurtz, L. T., 1945, Determination of total, organic, and available forms of phosphorus in soils. Soil Sci., 59: 39-45.

Celik, I., 2005, Land-use effects on organic matter and physical properties of soil in a southern Mediterranean highland of Turkey. Soil Tillage Res., 83:270-277.

Chang, E. H., Chung, R. S. and Wang, F. N., 2008. Effect of different types of organic fertilizers on the chemical properties and enzymatic activities of an Oxisol under intensive cultivation of vegetables for 4 years. Soil Sci. and Plant. Nutr., 54: 587-599.

Chesnin, L. and Yien, C. H., 1951, Turbidimetric determination of available sulphate. Soil Sci. Soc. Am. Proc., 15: 149-151.

Dharakanath, K., 1995, Sulphur status and forms in acid soils of Manipur. J. Indian Soc. Soil Sc.,43: 364-367.

Fu B, Chen L, Ma K, Zhou, H, and Wang, J., 2000. The relationships between land use and soil conditions in the hilly area of the loess plateau in northern Shaanxi, China. Catena. 39:69-78

Goldberg, S. and Glaubig, R. A., 1985. Boron adsorption on aluminum and iron oxide minerals. Soil Sci. Soc. Am. J., 49: 1374-1379.

Herojit Singh Athokpam, R. K., Kumarjit Singh, L. N., Singh, N., Gopimohan Singh., Nandini Chongtham and Kumar Singh, A. K., 2007, sulphur status and forms in acid soils of Manipur. Indian J. Agric. Res., 41(3): 205 - 209.

Hodgson, J.F., 1963. Chemistry of the micronutrients in soils. Advances in Agron.15: 119-149.

Jackson, M. L., 1973, Soil Chemical Analysis, Prentice Hall of India Private Limited, New Delhi.

John M. K., Chuah H. H. and Neufeld J. H., 1975, Application of improved azomethine- $\mathrm{H}$ method to the determination of boron in soils and plants. Anal. Lett. 8:559-568.

Korikanthimath, V. S., Gaddi, A. V., Anke Gowda, S. J. and Govardhan Rao, 2002, Soil fertility evaluation in plantation 
belt of Kodagu district, Karnataka Journal of Medicinal and Aromatic Plant Sciences., 24: 401-409.

Lindsay, W. L. and Norwell, W. A., 1978, Development of a DTPA soil test for $\mathrm{Zn}, \mathrm{Fe}, \mathrm{Mn}$ and $\mathrm{Cu}$. Soil Sci. Soc. Amer. J. 42: 421-428.

Liu Xl, He Yq, Zhang Hl, Schroder Jk, Li Cl, Zhou J, and Zhang Zy., 2010, Impact of land use and soil fertility on Distributions of soil aggregate fractions and some nutrients. Pedosphere. 20(5):666-673.

Nagaraja, M. S., 1997, Biomass turnover, nutrient status and biological processes in different land use Systems. Ph. D Thesis, UAS, Bangalore.

Nambiar, K. K. M., 1994, SoilFertility And Crop Productivity Under Long-Term Fertilizer Use In India. ICAR. New Delhi.

Neris J, Jiménez C, Fuentes J, Morillas G, and Tejedor M., 2012, Vegetation and landuse effects on soil properties and water infiltration of Andisols in Tenerife (Canary Islands, Spain). Catena.98:5562.

Powlson, D. S. and Johnston, A.E., 1994, Long term field experiments: Their importance in understanding sustainable agriculture. In D. J. Greenland and I. Szabolcs (eds), Soil Resilience and Sustainable Land Use, CAB International, Oxon, UK. pp. 422-451.
Rao, K. V., 1992, Dynamics of aluminium in base unsaturated soils of Karnataka. $P h$. D. Thesis, Univ. Agric. Sci., Bangalore (India).

Sarma, V. A. K., Krishnan, P. and Budihal, S. L., 1987, Laboratory Methods, NBSS Publn. No. 14, Tech. Bull., NBSS and LUP, Nagpur, India.

Stangel, P., Pieri, C. and Mokwuyne, U., 1994, Maintaining nutrient status of soils: Macronutrients. In D.J. Greenland and I. Szabolcs (eds) soil resilience and sustainable land use. CAB international, Oxon, UK., pp. 171-198.

Subbaiah, B. V. and Asija, G. L., 1956, A rapid procedure for the estimation of available nitrogen in soils. Current Science, 25:259-260.

Tisdale, S.L., Nelson, W.L.,Beaton,J. D. and Havlin, J. L., 1995, Soil fertility and fertilizer, $5^{\text {th }}$ Ed. Prentice-Hall of India, New Delhi. 684p.

Walkley, A. and Black, C. A., 1934, An examination of method for determining soil organic matter and a proposed modification of the chromic acid titration method. Soil Sci., 37: 29-38.

Wang J, Fu B, Qiu Y, and Chen, L., 2001, Soil nutrients in relation to land use and landscape position in the semi-arid small catchment on the loess plateau in China. J. Arid. Environ.,48:537-550.

\section{How to cite this article:}

Prabhudev Dhumgond, S.S. Prakash, C.A. Srinivasamurthy and Bhaskar, S. 2017. Soil Fertility Status as Influenced by Different Cropping Systems in Hill Zone Acid Soils of Karnataka, India. Int.J.Curr.Microbiol.App.Sci. 6(4): 670-678. doi: https://doi.org/10.20546/ijcmas.2017.604.082 